\title{
服部式䅡椎椎弓形成術と顤椎椎弓切除術の治療成績の比較検討
}

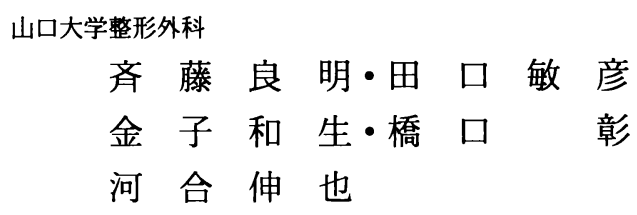

\section{Comparison of the Results of the Cervical Laminoplasty (Hattori's Method) and the Cervical Laminectomy}

\author{
Yoshiaki Saito, Toshihiko Taguchi, Kazuo Kaneko, \\ Akira Hashiguchi, and Shinya Kawai \\ Department of Orthopaedic Surgery, Yamaguchi University
}

\begin{abstract}
The purpose of this paper is to compare radiological changes after cervical laminoplasty and laminectomy. The subjects were 78 patients with myelopathy caused by the cervical spondylosis or the ossification of the posterior longitudinal ligament in the cervical spine. 61 cases were treated using Z-shaped laminoplasty (Hattori's Method) and 16 using laminectomy. The average age at the time of surgery was 57 , and the average follow-up period was 11 years and 2 months. The functional results were evaluated according to the Japanese Orthopaedic Association's scoring system. At the time of follow-up, the average recovery rate was $63 \%$ in the laminoplasty group, and $32 \%$ in the laminectomy group. In the laminoplasty group, the abnormality of alignment was greatly reduced in frequency and degree compared with the laminectomy group. The recovery rate was poor in patients with postoperative changes in the type of cervical spine curvature developed. Laminoplasty is considered to be superior to laminectomy in maintaining cervical alignment and preventing postoperative spinal deformities.
\end{abstract}

Key words : cervical laminoplasty (頝椎椎弓形成術), cervical laminectomy (頝椎椎弓切除術), spinal deformity (脊椎変形)

はじめに

1971 年, 服部は後方除圧と共に後方要素の再建を 行い, 頚椎の支持性を保持する頚椎椎弓形成術を考案 した．以後，当科では適応を選び一貫して服部式頝椎 椎弓形成術（以下形成術）を行っている. 今回, 本術 式の臨床成績, $X$ 線学的成績を調査し, 頝椎椎弓切除 術（以下切除術）と比較検討したので報告する.
対

象

1963 年より 1999 年までに当科で形成術および切除 術を施行した症例のうち術前, 退院時, 調查時の頝椎 X線機能撮影像を直接確認出来た 78 例を対象とした. 内訳は男性 57 例, 女性 21 例, 手術時年齢は 39 79 歳（平均 57 歳）であり, 追跡期間は 3 ケ月から 35 年 （平均 11 年 2 ケ月）であった，疾患別には頝椎症性脊 髄症（以下 CSM） 57 例, 頚椎後縦勒帯骨化症（以下 
OPLL） 21 例である. 術式別には形成術 62 例, 切除 術 16 例である.

$$
\text { 方法 }
$$

術後成績の評価は日整会頚随症治療成績判定基準 （以下 JOA score）を用いて，平林の改善率に準じ， 75\%以上を優，50\%〜 74\%を良，20\%〜49\%を可，0 \% 19\%を不変， $0 \%$ 未満を悪化の 5 段階で評価し， 改善度が優, 良を成績良好群それ以外を成績不良群と した．X線学的計測には，頚椎弯曲度は中間位におい て石原法 ${ }^{3)}$ による弯曲指数を求め, $5 \sim-5$ を直線型, - 5 より小さいものを後弯型, 5 より大きいあのを前 弯型として分類した．また，頚椎可動域については $\mathrm{C} 2$ および $\mathrm{C} 7$ 椎体後縁のなす角度を頚椎前屈, 後屈 像上で計測し，各々の和によって算出した ${ }^{2)}$.

今回は術後成績に影響を与える因子として手術時年 齢, 罹病期間, 術式, 術前 JOA score, 術前頚椎弯 曲度を検討し, 治療成績との関連性について分散分析 および分割表分析を用いて検討した。

\section{結果}

各術式の baseline character は表 1 の如くである. 調查時 JOA score の平均改善率は切除術では $32.3 \%$ に対して形成術では $62.6 \%$ であり，形成術で有意に良 好な結果が得られていた（ $\mathrm{p}=0.005 ）$ 。形成術におけ る術後成績に影響を与える因子としては, 手術時年齢, 術前 JOA score との関連性はなく, 罹病期間（ $\mathrm{p}=$ $0.03)$, 術前の頝椎弯曲型（ $\mathrm{p}=0.001 ）$ が影響を与えて いた。

術前の弯曲型は前弯型 58 例, 後弯型 7 例, 直線型 13 例であった．このうち術後に弯曲変化を認めた症 例は 22 例（28.2\%）であったが，退院時以降に弯曲 変化が発生した症例は 6 例（7.7\%）に過ぎなかった。 弯曲変化発生率を術式別に検討すると, 切除術では 16 例中 6 例（37.5\%）に対して形成術では 62 例中 16 例（25.8\%）と切除群に比べて発生率は低かった。術 前前弯型の 58 例について検討すると，調査時にも前
弯型が維持されたのは, 切除術で 9 例中 6 例 (66.7\%) であったが，形成術では 49 例中 40 例 （81.6\%）であり, 術式間で有意差を認めた（ $\mathrm{p}=0.042 ）$. 弯曲指数を用いた検討では, 全体として形成術で調查 時平均 -1.4 , 切除術で平均 -4.3 と術前に比べて減少 していたが, 術前に直線型あるいは後弯型の 20 例に 関しては形成術で平均 -0.7 に対して切除術では平均一 5.9 であり, 術前の弯曲形態に拘わらず形成術で術後 前弯の減少は少なかった.

弯曲変化発生と JOA score 改善率についての検討 では, 弯曲変化が発生した群 $(\mathrm{n}=22)$ では $38.9 \pm$ 37.3\%の改善に留まっていたが, 弯曲変化の発生しな かった群 $(n=56)$ では $63.2 \pm 38.6 \%$ の改善率が得ら れており, 弯曲变化の発生しなかった群で有意に良好 な結果が得られていた（ $\mathrm{p}=0.013 ）$. 頝椎可動域は両 術式共に減少していたが, その減少は入院時の術後早 い時期に生じていることが多く, 退院時以降の变化は 少なかった。

$$
\text { 考 察 }
$$

形成術の術後成績に影響を与える因子としては, 田 口ら ${ }^{8)}$ の報告之同様に, 発症後 1 年以内で術前に前弯 型を呈している症例で良好な成績が得られていた，弯 曲変化の発生した症例では JOA score 改善率が低下 していることから, 術後に弯曲変化の発生を予防する ことは重要であり，この点に関しては術前の弯曲形態 に拘わらず形成術に優れていた。

頝椎椎弓切除術後に後弯変化が出現するメカニズム としては, Sim ら`)は内的安定要素である勒帯, 骨複 合体の損失によって生じると述べており, 生体力学的 研究 ${ }^{5}$ や有限要素法 ${ }^{4}$ による検討からも手術侵襲に伴 う頝椎自体の支持性の低下が原因と報告されている. 一方, 藤ら ${ }^{9)}$ は家兔による実験から, 後方筋組織など の外的安定要素の重要性を述へ，鎧ら ${ }^{1)}$ は in vivo で は神経一筋系統による制御をうけると示唆しており, この変形の発生は個体差によって生じる可能性がある. しかし, 前述した如く, 形成術では切除術に比べて有

表 1 baseline character

\begin{tabular}{c|c|c|c}
\hline \hline & 形成術 & 切除術 & $P$ 値 \\
\hline 手術時年齢 & $59.1 \pm 11.3$ 歳 & $56.7 \pm 9.1$ & 0.37 \\
術前 JOA & $9.7 \pm 3.7$ 点 & $9.6 \pm 2.5$ & 0.96 \\
術前弯曲指数 & $13.5 \pm 6.7$ & $11.3 \pm 8.2$ & 0.71 \\
\hline
\end{tabular}


意に弯曲変化の発生が少なく，私達の家兔を用いた生 体力学的実験 ${ }^{6}$ からむ, ligamentous spine の剛性は 形成術で強いことから，この術後䅡椎の剛性の相違が 弯曲変化の発生に関与していると考えている. また, 頝椎可動域に関しては術後に減少するものの, 多くの 症例で退院時までに完成されており，以後頚椎に対し て制動的に働くことが予測される．以上のことから， 形成術は少なくとあアライメントを保つという点にお いて, 切除術に比して優れた術式と考えられる.

$$
\text { ま と め }
$$

服部式頝椎椎弓形成術と椎弓切除術の術後成績の検 討から，予後に影響を与える因子は，罹病期間，術前 の弯曲型であった．形成術では切除術に比べて前弯の 保持に優れていた.

\section{参考 文 献}

1）鎧 邦芳, 羽場 等: 脊椎損傷の診察に役立つバイオ
メカニクス，脊椎脊髄，12（6）：447-453，1999.

2）後藤澄雄 : 頚椎症. MB Orthop, 12（6）: 158-164, 1999.

3）石原 明：正常人の䅡椎柱弯曲に関するX線学的研究 日整会誌, $42 ： 1033-1044,1968$.

4) Kumaresan, S., et al. : Finite Element Modeling of Cervical Laminectomy with Graded Facetectomy. J. Spinal Disorders., $10: 40-46,1977$.

5) Nowinski, GP., et al. : A Biomechanical Comparison of Cervical Laminaplasty and Cervical Laminectomy with Progressive Facetectomy. Spine, 18 : 1995-2004, 1993.

6）斉藤良明ほか：家鬼における服部式頝椎椎弓形成術お よび椎弓切除術の術後頚椎支持性に関する検討. 整・災 外投稿中

7) Sim, FH., et al. : Swan-neck Deformity following Extensive Cervical Laminectomy. J. Bone Joint Surg., 56-A : 564-580, 1974.

8）田口敏彦ほか：頚椎症性脊䯣症の術後長期成績につい ての検討. 臨整外, 35:417-420, 2000.

9）藤真太郎：頝椎後方支持組織の役割に関する実験的検 討. 山口医学, 41 (1) : 1-10, 1992. 